\title{
Determinants of Audit Report Lag of Commercial Banks in Nepal
}

\author{
Bishnu Prasad Bhattarai, $\mathrm{PhD}^{1}$ \\ ${ }^{1}$ Academic Director / Business Unit Head, Excel Business College, Pokhara University Affiliated, New \\ Baneshwor, Kathmandu \& Faculty Member, Patan Multiple Campus, Faculty of Management, Tribhuvan \\ University, Patan Dhoka, Lalitpur, Nepal \\ Correspondence: Bishnu Prasad Bhattarai, Director / Business Unit Head, Excel Business College, Pokhara \\ University Affiliated, New Baneshwor, Kathmandu \& Faculty Member, Patan Multiple Campus, Faculty of \\ Management, Tribhuvan University, Patan Dhoka, Lalitpur, Nepal. ORCID ID: \\ https://orcid.org/0000-0001-8602-3198 E-mail: drbhattarai2019@gmail.com
}

Received: August 15, 2020

Accepted: September 21, 2020

Online Published: September 24, 2020

doi:10.5539/ijbm.v15n10p108

URL: https://doi.org/10.5539/ijbm.v15n10p108

\begin{abstract}
The purpose of the study to analyzed the determinants of audit report lag of commercial banks in Nepal. The secondary balance panel data of seven commercial banks for the period of 2013/2014 to 2017/ 2018, latest five years fresh data for the analysis. The sample have been choice from the convenience sampling technique. The descriptive statistics, correlational and casual comparative research design has been employed. The study has been selected audit report lag as dependent variable and return of total assets (ROA), leverage, size of bank, size of board, and bank age as independent variables. The result has been analysis by three different models like Pooled OLS, Fixed Effects and Random Effects Model with the help of Gretl Statistical Software version 1.9.4. The result of Poled OLS and Random Effects Model has appropriate of this cases. In the Fixed Effects Model has not prediction of statically because there is not any variable significant. The study found that leverage and board size are the determinants of audit report lag in the Nepalese commercial banks perspectives. The study also found that the minimum 18 days to maximum 242 days lag of audit report of sample banks. The study concluded that leverage and board size have major determinants of audit report lag in Nepalese samples banks perspectives.
\end{abstract}

Keywords: audit report lag, panel data, Nepal, profitability, leverage, bank size, board size, age

\section{Introduction}

The time difference between financial year end and audit report date is known as audit report lag or delay. The delay disclosure of accounting information effect its capital market (Asthon, John \& Robert, 1987). The annual report of companies have insight for user. The information which were disclosure in the company annual report basically useful for the user as well as investors to take investment decisions. The financial statement flow the information about performance of enterprises. The information has got timely better to the users for analysis in different angle. The delay production and discloser the audit report questionable for stakeholders (Ahmed \& Hossain, 2010). The audit report lag directly and indirectly gap of companies' information to the regulated bodies and investors for relevant decision making ((Dibia \& Onwuchekwa, 2013). The timely presentation of audit report produce without delay is better for the company itself, user and decision maker (Ustman, 2020). The days when audit report submitted by auditor after completion of fiscal year is known audit report lag. The accurate accounting information timely disclose is better for the company's investor, users as well as decision makers (Mazkiyani \& Handoyo, 2017).

The studies on audit report lag has been began more than five decades. The earliest study was done by Beaver (1968). Then, the studies have been continued by different scholars at different part of the world. Not yet, no one has been done such types of studies in the Nepalese context. To fulfill the gap of the study, the researcher has been felt to the study in this topic. The study has been fulfill the gap of literature for those who have been interested in this area in Nepal. In this connection, the issues of the study is: What are the determinants of audit report lag of commercial banks in Nepal? 
The purpose of the study to analyzed the determinants of audit report lag of commercial banks in Nepal. To full fill the objectives of the study, the scholar has been taken profitability, leverage, bank size, board size and age to determine the audit report lag.

The study found that leverage and board size are the determinants of audit report lag in the Nepalese commercial banks perspectives. The study also found that the minimum 18 days to maximum 242 days lag of audit report of sample banks.

To finalize the remaining of the study has been divided in to following sections. The second section of the study has been explained literature review in this subject matters. The section third has been analysis of research methodology. The fourth part of the study has been detailed to the study analysis where data presentation and results have been explain in different tests like descriptive statistics, correlation and regression analysis. The fifth part of section has been draw summary and conclusion with recommendation and final part of the study has been limitations and further scope of the study.

\section{Literature Review}

The studies on audit report lag has been began more than 52 years ago and the earliest study was done by Beaver (1968). Then, the studies have been continued by different scholars at different part of the world to date (2020). Some of major studies related with the study have been explained as follows.

Jaggi and Tsui (1999) have examined audit report lag of Hong Kong Companies. The study revealed that there is positive relation between audit report lag and financial risk index. They also found that low profitable enterprises have delays longer of audit report. At the point of view of family owned business they had taken short time period during the period of 1991-1993 of 393 sample companies.

El-Bannany (2008) has investigated the audit report lag of Egyptian 21 banks during the year 2004. The regression results showed that external auditor type, bank size, audit complexity in terms of the number of branches, audit complexity in terms of diversity level and bank profitability, all have a significant impact on the audit report lag but the exceptional items does not.

Lee and Jahng (2008) have examined audit report lag of Korean companies. The study found that audit report lag was negative relation with non- audit fees paid. The variables abnormal audit hours, provision of tax services, and internal control system for service had significant role for reduce the audit report lag.

Afify (2009) have analyzed that audit report lag of Egyptian 85 companies. The sample companies had submitted their report minimum 19 days to maximum 115 days delay. The corporate governance factors like board independence, duality of CEO and audit committee existence had positive affect on audit report delays. The control variable company size, industry and profitability have also significant effects with audit report lag.

Ahmed and Hossain, (2010) have identified audit reports lag of the 87 Bangladeshi listed companies. The results found that the average audit report delay was around 101 days. The earliest was 14 days, while the longer was 272 days. The variables audit type, financial company, profitability and size of company have significant effects of audit report lag. Which indicates that these variable inverse relation with audit report delay. Likewise type of audit report and leverage have significantly positive with audit report lag.

Apadore and Noor (2013) have analyzed the audit report lag of 843 Malaysian Companies for two year 2009 and 2010. The results of study shows that minimum 26 days and maximum 148 days was taken for audit report submission after fiscal year completion. The average time for audit report completion after fiscal year was 100 days. Similarly, the result reveals that audit committee size, ownership concentration, organization size, and profitability were significant with audit report lag. The other study variables has not significant role for audit report completion.

Ilaboya and Christian (2014) have investigated audit report lag of 40 Nigerian companies from 2007 to 2010. The variables board size, board independence, audit firm type, audit committee size and audit committee independence and firm size on audit report lag. The results revealed that board size, audit firm type, firm size had a significant effect while board independence and audit committee size had no significant effect on audit report lag. The study has recommended that government should make stringent policies and regulations on audit report lag. The professional accounting bodies should monitor auditing firms for early completion of any engagement, and good corporate governance practices should be fully implemented in Nigerian organizations in order to reduce incidence of audit report lag.

Hapsari, Putri and Arofah (2016) have determined the impact of profitability, solvency, and auditor's opinion to audit report lag of Indonesian mining companies. The study concluded that profitability and auditor's opinion 
have a negative significant influence on audit report lag of mining companies listed on Indonesia Stock Exchange while the solvency has no significant influence on audit report lag.

Mazkiyani and Handoyo (2017) have analyzed the factors that affect audit report lag of 332 public manufacturing companies in Indonesia from 2009 to 2012. The variables: company size, profitability, solvability, age of company, accounting firm size and audit committee has been employed to determine the audit report lag. The results shows that profitability and accounting firm size significantly influence audit report lag whereas, company size, solvability, age of company and audit committee does not influence audit report lag.

Tannuka (2018) has analyzed that the punctuality of audited financial report delivery from 2011 to 2015 in Indonesia. The variables such as company size, profitability, solvency, liquidity, and the size of KAP that affect audit report lag. The result shows that the profitability and size of KAP have a significant effect on Audit Report Lag whereas company size, solvency and liquidity have no significant effect on Audit Report Lag.

Fujianti and Satria (2020) have examined the factors that influence audit report lag of 91 manufacturing companies in Indonesia of two year the period (2015 and 2016). The factors were company size, profitability and corporate leverage. The random effect model was employed. The results showed that company size and profitability were significant effects on audit report lag. The leverage was insignificant effect on audit report lag. The large and higher profitable companies has completion of audit report on time.

Ustman (2020) has examined the factors affecting the audit report lag of 32 companies in Indonesia. The factors were solvency, firm size, and age companies. The shows that the solvency and company age have insignificant with audit report lag whereas firm size has significant effects on audit report lag.

The rigorous literature has been survey for the strong research methodology. From the literature survey, the present study has been drawn the research methodology as follows.

\section{Research Methodology}

In this study, seven commercial banks has been chosen out of 27 commercial banks. The secondary balance panel data for the period of 2013/2014 to 2017/ 2018. The reason behind the choosing of latest five years fresh data for the analysis. The sample also have been choice from the convenience sampling technique. The sample banks were NIC ASIA Bank, Standard Chartered Bank, Sanima Bank, Everest Bank, Agricultural Development Bank, Megha Bank, Prime Bank and Citizen Bank. The descriptive statistics, correlational and casual comparative research design has been employed.

\subsection{The Model}

The following model has been employed based on previous studies to determine audit report lag of commercial banks in Nepal.

$$
\mathrm{ARL}_{\mathrm{it}}=\beta 0+\beta 1 \mathrm{ROA}_{\mathrm{it}}+\beta 2 \mathrm{LEV}_{\mathrm{it}}+\beta 3 \mathrm{BSIZE}_{i t}+\beta 4 \mathrm{BODSIZE}_{\mathrm{it}}+\beta 5 \mathrm{AGE}_{\mathrm{it}}+\mathrm{e}_{\mathrm{it}}
$$

Where

$\beta 0=$ Constant term

$\beta 1$ to $\beta 5=$ Coefficient of Variables

ROA it $=$ Return on Assets of $i^{\text {th }}$ bank in year $t$

$L E V_{\text {it }}=$ Leverage of $i^{\text {th }}$ bank in year $t$

BSIZEit $=$ Bank Size of $i^{\text {th }}$ bank in year $t$

BODSIZEit $=$ Board of Director Size of $i^{\text {th }}$ bank in year $t$

$\mathbf{A G E}_{\text {it }}=$ Bank Age of $\mathrm{i}^{\text {th }}$ bank in year $\mathrm{t}$

$\mathrm{e}_{\mathrm{it}}=$ Error term

\subsection{Variables and Hypothesis}

The study has been selected audit report lag as dependent variable. The study also have been taken return of total assets (ROA), leverage, size of bank, size of board, and bank age as independent variables. The explanations about the measurement and hypothesis of the study have been described as follows. 


\subsubsection{Dependent Variable}

\subsubsection{Audit Report Lag}

Audit report lag is the difference time (number of days) between the banks' financial year end and the signing of the audit reports. The same calculation have been made of the previous studies were: Halme and Huse (1997), Jaggi and Tsui (1999), Xie et al. (2003), Cerbioni and Parbonetti (2007), Ezat and El-Masry (2008), Wu et al. (2008), Lee and Jahng (2008), El-Bannany (2008), Cormier et al. (2009), Afify (2009), Khasharmeh and Aljifri (2010), Ahmed and Hossain, (2010), Al-Ghanem and Hegazy (2011), Juanita and Satwiko (2012), Dibia and Onwuchekwa (2013), Apadore and Noor (2013), Ilaboya and Christian (2014), Hapsari, Putri and Arofah (2016), Hashim (2017), Mazkiyani and Handoyo (2017), Tannuka (2018), Karlina, Lindrianasari, Gamayuni (2018), Habib, Bhuiyan, Huang and Miah (2019), Abdillah, Mardijuwono and Habiburrochman (2019), Azizan (2019, Fujianti and Satria (2020), and Ustman (2020).

\subsubsection{Independent Variables}

The study also have been taken return of total assets (ROA), leverage, size of bank, size of board, and bank age as independent variables. Most of the studies were taken these variables. The independent variables of the study have descried as follows.

\subsection{Profitability (ROA)}

The profitability measure by net profit after tax on total assets. This variable has measure the efficiency of management. The organization have how much their assets have been utilized to return. It may also parameter of the audit report delay. The present study have assumed that higher profitable organization takes less time to audit report. The profitability has negative related with the audit report lag. The studies in support were Lee and Jahng (2008), El-Bannany (2008), Afify (2009), Ahmed and Hossain, (2010), Khasharmeh and Aljifri (2010), Apadore and Noor (2013), Hapsari, Putri and Arofah (2016), Mazkiyani and Handoyo (2017), Abdillah, Mardijuwono and Habiburrochman (2019), Azizan (2019), Habib, Bhuiyan, Huang and Miah (2019), and Fujianti and Satria (2020).

H1: The profitability has significantly negative relation with audit report lag.

\subsection{Leverage}

The leverage is the proportion of total debt with the amount of equity owned by the company. When the proportion of debt is higher than the equity, the formal procedures takes long time to finalize the audit. The priori study on the line were Lee and Jahng (2008), Ahmed and Hossain, (2010), Mazkiyani and Handoyo (2017), and Habib, Bhuiyan, Huang and Miah (2019). However, the leverage amount high intuitions have taken lower the time for audit, which is reverse relation each. The previous study on supported were Khasharmeh and Aljifri (2010) and Fujianti and Satria (2020). Hence, the study also expected negative relation to each other's.

H2: The leverage has significantly negative relation with audit report lag.

\subsection{Bank Size}

The bank size has been measure by natural logarithm of total asset. The higher bank size lower the audit repot lag and vice versa. The previous studies consistent with same line were Jaggi and Tsui (1999), Lee and Jahng (2008), Afify (2009), Khasharmeh and Aljifri (2010), Ahmed and Hossain, (2010), Dibia and Onwuchekwa (2013), Apadore and Noor (2013), Hashim (2017), Habib, Bhuiyan, Huang and Miah (2019), Fujianti and Satria (2020), and Ustman (2020). The previous study have positive direction were El-Bannany (2008), Al-Ghanem and Hegazy (2011), and Tannuka (2018). The present study hypothesis is as follows.

\section{H3: The bank size has significantly negative relation with audit report lag.}

\subsection{Board Size}

The total numbers of board of directors reflect the board size of the bank. It is also called corporate governance body. The large the board size delay the audit report and shorten the board size have less time takes the audit report. The results of study in the favor were Halme and Huse (1997), Xie et al. (2003); Cormier et al. (2009), Afify (2009), Ilaboya and Christian (2014), and Azizan (2019). The present study has also expected negative relation.

H4: The board size has significant negative relation with audit report lag.

\subsection{Bank Age}

The year of foundation of the company has been taken as age of company in this study. The study has assumed 
that older institutions have made and follows the producer as per rules and regulations. So that they have less time to do audit. The older organization have more experiences so that older organization have taken less time audit report lag. The younger organization have less experience to control accounting system so that they have taken much time to do audit. The time for the reporting definitely high and delay. The priori studies in the same conclusion were Dibia and Onwuchekwa (2013), Ilaboya and Christian (2014), and Karlina, Lindrianasari, Gamayuni (2018). The present study also expected negative relation.

H5: The age of the banks have significantly negative relation with audit report lag.

\subsection{Summary of Variables}

The selected study variable variables, measurements, nation, source and hypothesis (expected sign) have been presented in the Table1.

Table 1. Summary of variables, measurements, nation, source of findings and expected sign

\begin{tabular}{|c|c|c|c|c|}
\hline Variables & Measurement & Notation & Source of Study & $\begin{array}{l}\text { Expected } \\
\text { relation } \\
\text { with ARL } \\
\end{array}$ \\
\hline \multicolumn{5}{|c|}{ Dependent Variables } \\
\hline $\begin{array}{l}\text { Audit } \\
\text { Report Lag }\end{array}$ & $\begin{array}{l}\text { The Number of } \\
\text { Days between the } \\
\text { Banks' Financial } \\
\text { Year End and the } \\
\text { Signing of the } \\
\text { Audit Reports. }\end{array}$ & ARL & $\begin{array}{l}\text { Halme and Huse (1997), Jaggi and Tsui (1999), Xie et al. (2003), Cerbioni } \\
\text { and Parbonetti (2007), Ezat and El-Masry (2008), Wu et al. (2008), Lee and } \\
\text { Jahng (2008), El-Bannany (2008), Cormier et al. (2009), Afify (2009), } \\
\text { Khasharmeh and Aljifri (2010), Ahmed and Hossain, (2010), Al-Ghanem } \\
\text { and Hegazy (2011), Juanita and Satwiko (2012), Dibia and Onwuchekwa } \\
\text { (2013), Apadore and Noor (2013), Ilaboya and Christian (2014), Hapsari, } \\
\text { Putri and Arofah (2016), Hashim (2017), Mazkiyani and Handoyo (2017), } \\
\text { Tannuka (2018), Karlina, Lindrianasari, Gamayuni (2018), Habib, Bhuiyan, } \\
\text { Huang and Miah (2019), Abdillah, Mardijuwono and Habiburrochman } \\
\text { (2019), Azizan (2019, Fujianti and Satria (2020), and Ustman (2020) }\end{array}$ & N/A \\
\hline
\end{tabular}

\begin{tabular}{|c|c|c|c|c|}
\hline \multicolumn{5}{|c|}{ Independent Variable } \\
\hline $\begin{array}{l}\text { Profitability } \\
\text { (ROA) }\end{array}$ & $\begin{array}{l}\text { Net Profit After } \\
\text { Tax to Total } \\
\text { Assets }\end{array}$ & ROA & $\begin{array}{l}\text { (+) Juanita and Satwiko (2012) and Tannuka (2018) } \\
\text { (-) Lee and Jahng (2008), El-Bannany (2008), Afify (2009), Ahmed and } \\
\text { Hossain, (2010), Khasharmeh and Aljifri (2010), Apadore and Noor (2013), } \\
\text { Hapsari, Putri and Arofah (2016), Mazkiyani and Handoyo (2017), } \\
\text { Abdillah, Mardijuwono and Habiburrochman (2019), Azizan (2019), } \\
\text { Habib, Bhuiyan, Huang and Miah (2019), and Fujianti and Satria (2020) }\end{array}$ & Negative \\
\hline $\begin{array}{l}\text { Solvency } \\
\text { (Leverage) }\end{array}$ & $\begin{array}{l}\text { Debt to Equity } \\
\text { Ratio (Total } \\
\text { liabilities to Total } \\
\text { Equity) }\end{array}$ & LEV & $\begin{array}{l}\text { (+) Lee and Jahng (2008), Ahmed and Hossain, (2010), Mazkiyani and } \\
\text { Handoyo (2017), and Habib, Bhuiyan, Huang and Miah (2019) } \\
\text { (-) Khasharmeh and Aljifri (2010) and Fujianti and Satria (2020) } \\
\text { (No Sig) Hapsari, Putri and Arofah (2016), }\end{array}$ & \\
\hline Bank Size & $\begin{array}{l}\text { Natural } \\
\text { Logarithm of } \\
\text { Total Assets }\end{array}$ & BSIZE & $\begin{array}{l}\text { (+) El-Bannany (2008), Al-Ghanem and Hegazy (2011), and Tannuka } \\
\text { (2018) } \\
\text { (-) Jaggi and Tsui (1999), Lee and Jahng (2008), Afify (2009), Khasharmeh } \\
\text { and Aljifri (2010), Ahmed and Hossain, (2010), Dibia and Onwuchekwa } \\
\text { (2013), Apadore and Noor (2013), Hashim (2017), Habib, Bhuiyan, Huang } \\
\text { and Miah (2019), Fujianti and Satria (2020), and Ustman (2020) }\end{array}$ & Negative \\
\hline Board Size & $\begin{array}{l}\text { Total Numbers of } \\
\text { Boards of } \\
\text { Directors }\end{array}$ & BODSIZE & $\begin{array}{l}\text { (+) Cerbioni and Parbonetti (2007), Ezat and El-Masry (2008), Wu et al. } \\
\text { (2008) } \\
\text { (-) Halme and Huse (1997), Xie et al. (2003); Cormier et al. (2009), Afify } \\
\text { (2009), Ilaboya and Christian (2014), and Azizan (2019) }\end{array}$ & Negative \\
\hline Bank Age & $\begin{array}{l}\text { Year } \\
\text { Foundation } \\
\text { Banks }\end{array}$ & AGE & $\begin{array}{l}\text { (-) Dibia and Onwuchekwa (2013), Ilaboya and Christian (2014), and } \\
\text { Karlina, Lindrianasari, Gamayuni (2018), }\end{array}$ & Negative \\
\hline
\end{tabular}

Source: Literature Survey by Researcher (2020). 


\section{Results and Discussion}

\subsection{Descriptive Statistics Analysis}

The descriptive statistics summary has been presented in Table 2. The average audit repot lag of Nepalese sample commercial banks were 118 days. The early audit report reporting time was 18 days and the late interval of audit was 242 days.

Table 2. Summary statistics, using the observations 1:1 - 8:5

\begin{tabular}{lllll}
\hline Variable & Min & Max & Mean & S.D. \\
\hline ARL & 18.0 & 242. & 118. & 62.9 \\
ROA & 0.970 & 3.12 & 1.87 & 0.402 \\
LEV & 4.12 & 13.7 & 8.27 & 2.44 \\
BSIZE & 17.2 & 25.9 & 24.6 & 1.74 \\
BODSIZE & 5.00 & 10.0 & 7.30 & 1.29 \\
AGE & 4.00 & 32.0 & 14.8 & 7.86 \\
\hline
\end{tabular}

Source: Annual Report of Sample commercial banks and Results were drawn from Gretl Statistics Software 1.9.4.

The average return on assets was 1.87 percent. It shows that management of banks has utilized its asset to earn profit was 1.87 percent. The maximum and minimum leverage were 4.12 percent and 13.7 percent. The average board of directors govern by banks were 7 plus. The minimum board of directors were 5 people and maximum people in the board were 10 directors. The average banks age of sample banks 14.8 years.

\subsection{Correlation Analysis}

The Pearson correlation coefficient of study variable has been presented in the Table 3. Audit report lag was dependent variable and return on assets, leverage, bank size, board size and age of banks were independent variables.

Table 3. Correlation coefficients, using the observations $1: 1-8: 5,5 \%$ critical value (two-tailed) $=0.3120$ for $\mathrm{n}=$ 40

\begin{tabular}{lllllll}
\hline ARL & ROA & LEV & BSZE & BODSIZE & AGE & Variables \\
\hline 1.0000 & 0.2846 & -0.5254 & 0.2970 & 0.3063 & -0.1148 & ARL \\
& 1.0000 & -0.4756 & 0.2671 & 0.0204 & 0.1276 & ROA \\
& & 1.0000 & -0.1819 & 0.0622 & 0.2099 & LEV \\
& & 1.0000 & 0.1832 & 0.2340 & BSIZE \\
& & & 1.0000 & -0.4317 & BODSIZE \\
\hline
\end{tabular}

Source: Annual Report of Sample commercial banks and Results are Drawn from Gretl Software 1.9.4 Version.

There is positive relation between profitability, bank size, board size with audit report lag. However, the leverage and age of banks have negative relationship between audit report lag. The correlation coefficient between independent variables have less than 0.30. It shows that there is low correlation between the independent variables. There is no multicollinearity problem of independent variables. It is also supported by VIF which is less than 2 each independent variables (see Table 4). So that that variables that have choice for the model is appropriated at the collenearity point of view. Hence the study has been further calculation of regression analysis.

\subsection{Regression Analysis}

Table 4 has been presented regression analysis of study variables. The result has been analysis by three different models like Pooled OLS, Fixed Effects and Random Effects Model with the help of Gretl Statistical Software version 1.9.4. The result of Poled OLS and Random Effects Model has appropriate of this cases. In the Fixed Effects Model has not prediction of statically because there is not any variable significant. The Pooled OLS and Random Effects Models have predicts same results. The further study has explained base on these two models. There is positive and statistically significant result found between the leverage and audit report lag. It shows that the banks have increases in leverage, the interval of audit report time has decreases. It is also further explain that 
higher the leverage lower would be the time interval of audit report lag of the sample banks. The result of the study consistent with studies of Khasharmeh and Aljifri (2010) and Fujianti and Satria (2020). Whereas the study results contrary with the studies of Lee and Jahng (2008), Ahmed and Hossain, (2010), Mazkiyani and Handoyo (2017), and Habib, Bhuiyan, Huang and Miah (2019).

The board size has positive and statistically significant with audit report lag. It shows that higher board members the interval of audit report lag. The study result has not supported priori hypothesis of this study. The result inconsistent with the study results were Cerbioni and Parbonetti (2007), Ezat and El-Masry (2008), Wu et al. (2008).

Table 4. Regression results of determinants of audit report lag

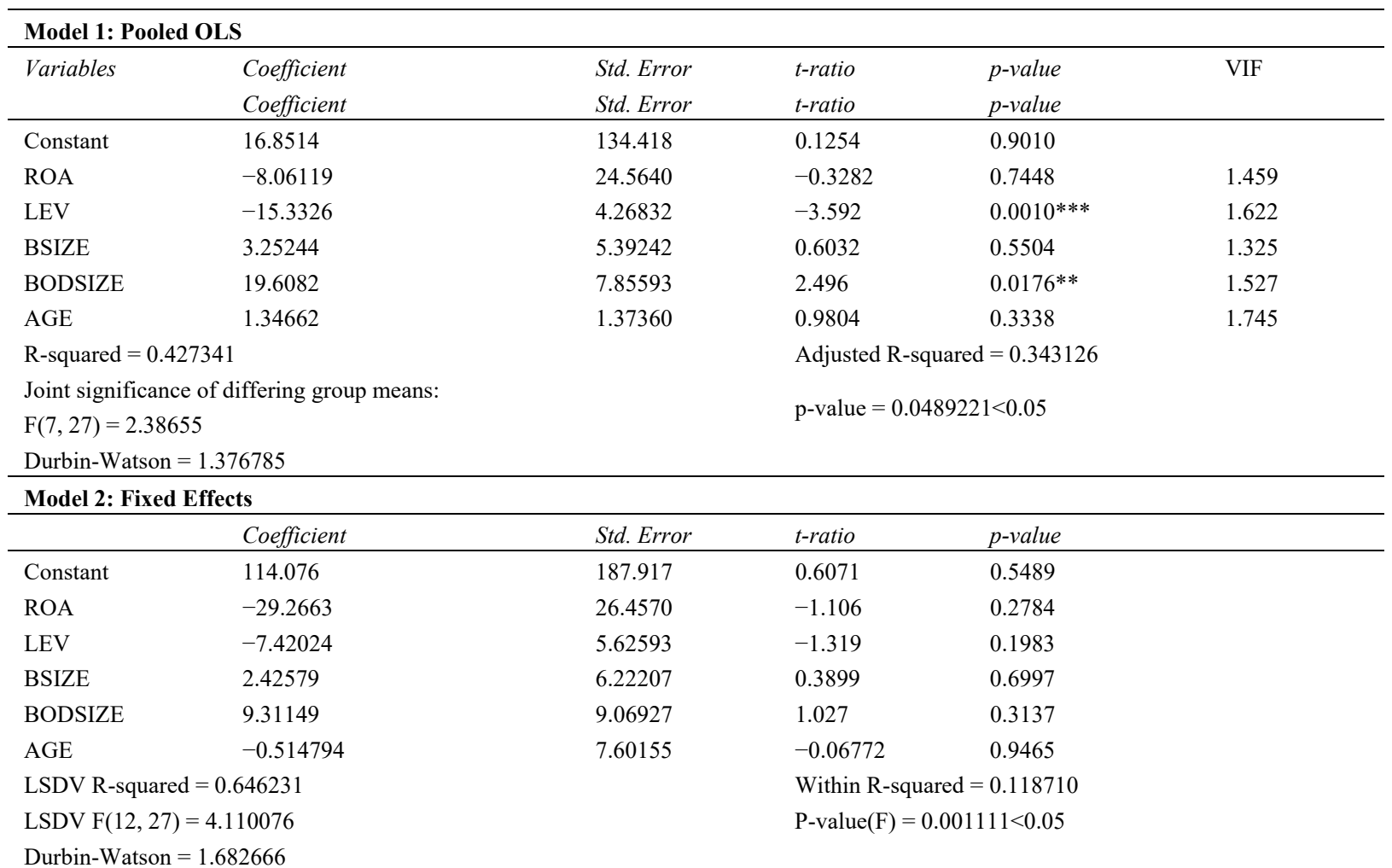

Durbin-Watson $=1.682666$

\begin{tabular}{|c|c|c|c|c|}
\hline & Coefficient & Std. Error & $Z$ & p-value \\
\hline Constant & 64.8159 & 143.471 & 0.4518 & 0.6514 \\
\hline ROA & -16.8734 & 24.3405 & -0.6932 & 0.4882 \\
\hline LEV & -11.2083 & 4.38851 & -2.554 & $0.0106 * *$ \\
\hline BSIZE & 2.63076 & 5.30496 & 0.4959 & 0.6200 \\
\hline BODSIZE & 14.2472 & 7.75046 & 1.838 & $0.0660^{*}$ \\
\hline AGE & 0.590751 & 1.90102 & 0.3108 & 0.7560 \\
\hline \multicolumn{3}{|c|}{ Breusch-Pagan Test Statistic : } & \multicolumn{2}{|c|}{ Hausman Test Statistics : } \\
\hline \multicolumn{3}{|c|}{$\mathrm{LM}=0.366619$} & \multicolumn{2}{|c|}{$\mathrm{H}=6.59709$} \\
\hline \multicolumn{3}{|c|}{ p-value $=\operatorname{prob}($ chi-square $(1)>0.366619)=0.544853>$} & \multicolumn{2}{|c|}{$\mathrm{p}$-value $=\operatorname{prob}($ chi-square $(5)>6.59709)$} \\
\hline \multicolumn{3}{|l|}{0.05} & \multicolumn{2}{|c|}{$=0.252371>0.05$} \\
\hline \multicolumn{5}{|c|}{ Durbin-Watson $=1.682666$} \\
\hline
\end{tabular}

Note. ${ }^{* *}$. Correlation is significant at the 0.01 level (2-tailed), $* *$. Correlation is significant at the 0.05 level (2-tailed). ${ }^{*}$ Correlation is significant at the 0.10 level (2-tailed).

Source. Annual Report of Sample commercial banks and Results are drawn from Gretl Software 1.9.4 Version.

The others variable profitability has negative association with audit report lag but not statistically significant. It shows that profitability has not effect audit report interval. Rest two variables bank size and has positive but statistically significant with audit report lag. The size of bank and age bank were not determinants of audit report 
lag of Nepalese sample banks perspectives.

\section{Summary and Conclusion}

Audit report lag is the time span for completing an audit of annual report conducted by the auditor. Audit report lag is very important because it can have an impact on the timeliness of accounting information presentation to be used as a decision maker by managers or external parties. The studies on audit report lag has been began more than five decades. The earliest study was done by Beaver (1968). Then, the studies have been continued by different scholars at different part of the world. Not yet, no one has been done such types of studies in the Nepalese context. To fulfil the gap of the study, the researcher has been felt to the study in this topic. The purpose of the study to analysed the determinants of audit report lag of commercial banks in Nepal. The secondary balance panel data of seven commercial banks for the period of 2013/2014 to 2017/ 2018, latest five years fresh data for the analysis. The study found that leverage and board size are the determinants of audit report lag in the Nepalese commercial banks perspectives. The study also found that the minimum 18 days to maximum 242 days lag of audit report of sample banks. The study concluded that leverage and board size have major determinants of audit report lag in Nepalese samples banks perspectives.

\section{Limitations and Scope of Future Study}

This study has been limited only banking industries and secondary data based. The sample size is relatively small and so that the results may not applicable to generalization. The scope of further study has been summarized as follows. The different sample like manufacturing sector, hotel sector and trading sector will be used. The other study variables along with this study variable or separate variables will be used to measure audit report lag. This data has been analyzed through SPPSS and multiple regression analysis. The future study can take the qualitative data, different technique and software like SmartPLS, WarpPLS and AMOS will be explore for the audit report lag. The cross countries data will be also used for determine the audit report lag.

\section{References}

Abdillah, M. R., Mardijuwono, A. W., \& Habiburrochman, H. (2019). The effect of company characteristics and auditor characteristics to audit report lag. Asian Journal of Accounting Research, 4(1), 129-144. https://doi.org/10.1108/AJAR-05-2019-0042

Afify, H. A. E. (2009). Determinants of audit report lag: Does implementing corporate governance have any impact? Empirical evidence from Egypt. Journal of Applied Accounting Research, 10(1), 56-86. https://doi.org/10.1108/09675420910963397

Ahmed, A. A. A., \& Hossain, M. S. (2010). Audit report lag: A study of the Bangladeshi listed companies. ASA University Review, 4(2), 49-56. Retrieved from https://ssrn.com/abstract=3406733

Alali, F. A., \& Elder, R. J. (2014). Determinants of audit report lag in the banking industry: updated evidence. International Journal of Accounting, Auditing and Performance Evaluation, 10(4), 364. https://doi.org/10.1504/ijaape.2014.066391

Al-Ghanem, W., \& Hegazy, M. (2011). An empirical analysis of audit delays and timeliness of corporate financial reporting in Kuwait. Eurasian Business Review, 1(1), 73-90.

Apadore, K., \& Noor, M. M. (2013). Determinants of Audit Report Lag and Corporate Governance in Malaysia. International Journal of Business and Management, 8(15), 151-163.

Asthon, R. H., John, J. W., and Robert, K. E. (1987). An empirical analysis of audit delay. Journal of Accounting Research, 25(2), 275-292.

Azizan, S. (2019). Ceo's gender, power, ownership: roles on audit report lag. Management \& Accounting Review, 18(2), 245-273.

Cerbioni, F., \& Parbonetti, A. (2007). Exploring the effects of corporate governance on intellectual capital disclosure: an analysis of European biotechnology companies. European Accounting Review, 16(4), $791-826$.

Cormier, D., Ledoux, M. J., \& Magnan, M. (2009). The use of web sites as a disclosure platform for corporate performance. International Journal of Accounting Information Systems, 10(1), 1-24.

Dibia, N. O., \& Onwuchekwa, J. C. (2013). An examination of the audit report lag of companies quoted in the Nigeria stock exchange. International Journal of Business and Social Research (IJBSR), 3(9), 8-16.

El-Bannany, M. (2008). Factors affecting audit report lag in banks: The Egyptian case. Corporate Ownership \& Control, 5(3), 54-61. 
Ezat, A., \& El-Masry, A. (2008). The impact of corporate governance on the timeliness of corporate internet reporting by Egyptian listed companies. Managerial Finance, 34(12), 848-867.

Fujianti, L., \& Satria, I. (2020). Firm size, profitability, leverage as determinants of audit report lag: Evidence from Indonesia. International Journal of Financial Research, 11(2), 61-67. https://doi.org/10.5430/ijfr.v11n2p61

Habib, A., Bhuiyan, M. B. U., Huang, H. J., \& Miah, M. S. (2019). Determinants of audit report lag: A metaanalysis. Int $J$ Audit., 23, 20-44. https://doi.org/10.1111/ijau.12136

Halme, M., \& Huse, M. (1997). The influence of corporate governance, industry and country factors on environmental reporting. Scandinavian Journal of Management, 13(2), 137-157.

Hapsari; A. N., Putri, N. K., \& Arofah, T. (2016). The influence of profitability, solvency, and auditor's opinion to audit report lag at coal mining companies. Binus Business Review, 7(2), 197-201. https://doi.org/10.21512/bbr.v7i2.1685

Hashim, U. J. B. (2017). Does ownership characteristics have any impact on audit report lag? evidence of Malaysian listed companies. World Applied Sciences Journal, 35(9), 1826-1838. https://doi.org/10.5829/idosi.wasj.2017.1826.1838

Hassan, Y. M. (2016). Determinants of audit report lag: evidence from Palestine. Journal of Accounting in Emerging Economies, 6(1), 13-32. https://doi.org/10.1108/JAEE-05-2013-0024

Ilaboya, O. J., \& Christian, I. (2014). Corporate Governance and Audit Report Lag in Nigeria. International Journal of Humanities and Social Science, 4(13), 172-180.

Jaggi, B., \& Tsui, J. (1999). Determinants of audit report lag: further evidence from Hong Kong. Accounting and Business Research, 30(1), 17-28. https://doi.org/10.1080/00014788.1999.9728921

Jouini, F. (2018). Cost of debt, corporate disclosure and audit report lag. EuroMed J. of Management, 2(3), 240. https://doi.org/10.1504/emjm.2018.093225

Juanita, G., \& Satwiko, R. (2012). Pengaruh Ukuran Kantor Akuntan Publik, Kepemilikan, Laba Rugi, Povitabilitas dan Solvabilitas terhadap Audit Report Lag. Jurnal Bisnis dan Akuntansi, 14(1), 31-40.

Karlina, L., \& Gamayuni, R. R. (2018). Determinant analysis of audit report lag in Regional Governments in Indonesia. International Journal of Scientific \& Technology Research, 7(4), 105-110.

Khasharmeh, H. A., \& Aljifri, K. (2010). The timeliness of annual reports in Bahrain and the United Arab Emirates: An empirical comparative study. The International Journal of Business and Finance Research, $4(1), 51-71$.

Lee, H. Y., \& Jahng, G. J. (2008). Determinants of audit report lag: Evidence from Korea - An examination of auditor-related factors. The Journal of Applied Business Research, 24(2), 27-44.

Mazkiyani, N., \& Handoyo, S. (2017). Audit report lag of listed companies in Indonesia Stock Exchange. Journal Aplikasi Bisnis, 17(1), 77-95. https://doi.org/10.20885/jabis.vol17.iss1.art5

Tannuka, S. (2018). Pengaruh ukuran perusahaan, profitabilitas, solvabilitas, likuiditas, dan ukuran kap terhadap audit report lag (studi empiris pada perusahaan properti, real estate, dan konstruksi bangunan yang terdaftar di bursa efek Indonesia periode 2011-2015). Jurnal Muara Ilmu Ekonomi dan Bisnis, 2(2), 354-368.

Ustman. (2020). The effect of solvency, firm size, age companies on audit report lag in Indonesian company. Research Journal of Finance and Accounting, 11(2), 17-22.

Wu, C., Wu, C., \& Liu, V. (2008). The release timing of annual reports and board characteristics. The International Journal of Business and Finance Research, 2(1), 103-108.

Xie, B., Davidson, W. N., \& DaDalt, P. J. (2003). Earnings management and corporate governance: the role of the board and the audit committee. Journal of Corporate Finance, 9(3), 295-316.

\section{Copyrights}

Copyright for this article is retained by the author(s), with first publication rights granted to the journal.

This is an open-access article distributed under the terms and conditions of the Creative Commons Attribution license (http://creativecommons.org/licenses/by/4.0/). 